the blle passages, so that should the Infiammatory tissue In the pancreas further contract and cause Increased pressure on the blle duct, no jaundice will occur, and, should the Inflammatory process pass away, the patient wlll not be distressed by the preaence of a blliary fistula or inconvenienced by the absence of the bile from the Intestines; moreover, there will not be the anxiety of any further operation to face, as there would be after a cholecystotomy. Bat, besides the relief of jaundice, the operation acts on the pancreas by relieving tension, and thus enabling the gland to discharge its contents, which when infected and imprisoned in the ducts tends to keep up inflammation, and to lead alter a time to atrophy of the gland substance proper and the formation of fibrous tissue.

It will be gathered from the foregoing arguments that I believe cholecystenterostomy to be the operation of cholce for the treatment of interstitial pancreatitis, and only In case of absence of or contraction of the gall bladder, or In case of unusual difficultles from adhesions or from the serious condition of the patient, would I counsel cholecystotomy or choledochotomy belng done.

Pancreatio Iithiasis.

Pancreatlc calcull are rare, about 80 cases only having been recorded, and surgical treatment of this condition is so uncommon that I can only find reports of five operations.

Pancreatic lithlasis is apparently the result of catarrh of the ducts with stagnation of secretion, and instead of calcull belng formed, the ducts moy actually be lined with calcareous material. To this condition I have applied the term " pancreolithic catarrh," a condition which is simu lated in the blle pagsages by cholelitbic catarrb.

From the diagnostle polnt of view the composition of pancreatlc calculi is important, since the presence of lime galts renders them opague to the $x$ rays, a fact which I bad the honour to polnt out first in the Hunterlan Ie tures,

The value of thls diagnostic method, which is demonstrated In Figs. 14 and 15, is, of conrse, limited by the depth of the pancreas from the surface, but in exceptional cases it may prove of service.

Although the normal pancreatic secretion contains no calcium carbonate, it is interesting to note that in all cases of interstitlal pancreatitls crystals of calcium oxalate are lound in the urine except when blle salts are present, In which case the bile aclds take them up.

The ultimate effect of pancrestic lithlasis is towards complete destruction of the gland by a process of interstl tlal pancreatitis ending in fibrosis.

Sargery offers a reasonable chance of cure it the disease is attacked In an early stage, 88 in a case that I operated on in February, 1803, in which I removed calcali from the ducts of Wirsung and Santorinl by direct incision into the pancreas and from the termination of the duct by opening the duodennm and laying open the papilla. The patlent, a lady of 61 , is now well, over five years later.

\section{Cancer of Panoreas}

Cancer of the pancreas is much more common than w88 previously recognized, as secondary growths in the liver were at one time frequently mlstaken for the original disease.

My experience of the disease is that it is in the greater number of cases practically painlees, espectally in its earlier stages, and when the body or tall of the gland is affected the only avallable evidence of the disfase may be fallure of health and loss of flesh, together with signs of disturbed metabolism; as revealed by examination of the urine and faeces; for it is to be remembered that obstruction of the ducts by a neoplasm induces chronic inflammatory changes in the gland beyond the obstruc. tion.

When the head of the oland is affected the common bile duct becomes obstructed, and jaundice rapldly becoming Intense and absolute, manifests itselt, producing charac teristic signs of the disesse-rapld Joss of flesh and janndice of palnless onset, with distension of the gall bladder-conditions which may be simulated sometimes by chronic interstitial pancreatitis. In the latter case it shonld, however, be noted that the pancreatic reaction will afford valuable help in diagnosis.

While cancer or sarcoma of the head of the pancreas is necessarily rapidly fatal and incupable of marked rellef either by medical or surgical treatment, yet when the disesse invades the distal part of the gland it is capable of removal if recognized sufficlently early, as shown by the results of 16 recorded operations, of whlch 8 recoverf $d$.

Even the palliatlve operations of short.circaiting the obstruction by cholecystenterostomy or draining the bile passages by cholerystotomy are peculiarly falal in maligoant cases, and the rellet afforded is merely temporary. Such operations can therefore only be justlfiable if undertaken in the hope that the disease may prove to be inflammatory and not malignant, in which case cholecystenterostomy has proved successful in 97 per cent. of cases.

\section{FRACTURE OF THE PATELlA TREATED BY} MOBILIZING THE LOWER FRAGMENT.

By J. LYNN THOMAS, C.B., F.R C.S., HONORARY SURGRON TO THE CARDIFF INFIRMARY AND THE HAMADRYAD HOSPITAL.

Tre interesting and most instruclive paper in the JouRnar of April 11th, p. 849, by Lord Lister, our revf red master, induces me to record a method I auccessfully adopted in a case that was sent to me in 1802 by Mr. Wyndham Randall, from the Bridgend Workhouse Hospital.

C. D., a labourer, aged 43, fractured hls patella in July, 1801, but did not consult a doctor for six'weeks. Varlous methods of non. operative treatment were trled bat proved ufeless, as apparently no: attempt at unlon took place between the fragments.

When I exsmined him there was a gap of about $1 \frac{1}{2}$ In. between the fragments, and nothing but skin apparently exlsted in the gap between the examining fingers and the temoral trochlear ourface.

On May 6th, 1902, I operated, and falling to get the fragments to within $\frac{1}{2}$ in. of each other by traction, and reallzlng that division of the quadriceps $\in$ xtensor muscle

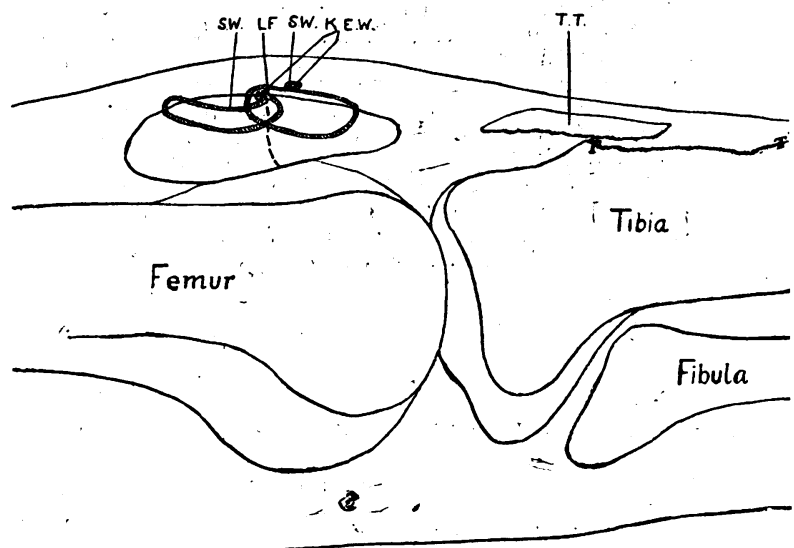

The anticathode was placed so as to show the gap between the tubercle and the tibia. hence the overlapping of the thadows of will $L F$, line of fracture ; $K \mathrm{E}$ w, bpots on ends of wires; $T T$, tubercle of tibia detached from between $\mathrm{T}$ and $\mathrm{T}$.

13 followed by much werkness of the llmb, I decided to attempt to bring the lower fragment towards the upper by mobllizlng it. This was readily done, as I took advantage of my experlence in the performance of arthrotomles and excision of the knee.joint by Kocher's excellent method of the curved external incision and chiselling off the tubercle of the tibla, and applied it to this case. After making a long curved inclsion well down over the shin, the tabercle of the tibla with the ligamentum patellae attached to it was chiselled off from without, care being taken not to detach the tendinous and periosteal attachments along its inner edge. By forclble traction upon the lower fragment of the patella and its ligament, the fragments were: $800 \mathrm{n}$ brought into contact, and their bared surfaces were kept in apposition by means of two loops of silver wire. The tubercle of the tibia retained considerable strength of anchorage in 1 ts 
displaced position by means of the untorn fibrous attachments of the ligamentum patellae along its inner slde. The wound was closed without drainage, and the patlen left the Infirmary on June 5th. Nothing could be more satisfactory than the Immediate result of mobllizing the lower Iragment, whilst the lunctional result in time was slso satisfactory.

I took a sklagraph of the knee about a fortnight after the operation, and Mr. S. W. Allen kindly made from it the outline here reproduced in order to show the new position of the tubercle of the tibla, and the limitation of its range of displacement upwards towards the kneejoint.

Lord Lister's article is a notable contribution towards the conservative treatment of the hitherto masterfal quadriceps extensor in the class of cases described by him.

\section{A CASE OF ECTOPIC GESTATION WITH UNUSUALLY EARLY SYMPTOMS.*}

Bт E. A. SEARLE, B.A., M.D., B.OF., B.A.O.Dणв, In the British Mrdioal Journat of May 25th, 1907, Dr. Nigel Stark reported a case of unusually early rupture of the gravid tabe. In his case menstruation ended May 11th, and rupture occurred, without any prevlous slgn or symptom, on May 28th-geventeen days later. He dated conception from May 19th, only nine days before rupture. My case is chlefly interesting from the verg early occurrence of symptoms.

\section{History.}

A healthy 2-para of 25 years, married three years, had a normal period of five days ending June 15tb, 1906. The earliest possible date of conception was June 17th. On July 1st (fourteen days later) she was seized with a very severe attack of spasmodic pain in the lower right abdominal region, which began with vomiting and lasted from two to three hours. The temperature was subnormal, and the palse fell to 60 from tts usual rate of 80 circa. There was a moderate amount of collapse with greyish pallor. In the region of the right lliac fosss tenderness was very marked but no musoular rigldity was present. Her condition rapidly improved and she was getting about the house again, when a simlilar attack occurred on the evening of July 4 th. Additional festures on this oocaon the evening of July 4th. Additional features on this oocasion were painfal micturition, and a slight blood-stal

Next day I made a vaginal examination and found a dlstinct fullness, with marked tenderness in the right fornix and behind the uterus. The cervix seemed to be shorter and more flattened out than usual. By this time tbe vaginal discharge had cessed, but defaecation becsme painful, and so continued to the end of the illness. After a few days she was fit again for household duties.

On July 9th-the day menstruation was due-a chocolsteOn July 9th-the day menstruation was due-a chocolate-
coloured vaginal discharge showed for the first time; it was coloured vaginal discharge showed for the first time; It was first sign that seemed to confirm my suspicions of ectoplc gestation.

Three days later-July 12th - a discharge began and continued like an ordinary severe "period " to J uly 19th. Daring this a third attack of abdominal pain oocurred on July $16 \mathrm{th}$. less severe, but more noticsably spasmodic in character, and not attended by vomiting as the previons attacks had been.

Next dey there was a similar seizare, during and after which some blood clots came awsy. On examination of thls discharge I found distlnct decidual remains; thls discovery was I found distinct decidual

sufficient to confirm my fears.
On July 19th the discharge ceased. By this time the patient began to foel and to look very miserable, and was losing weight and strength.

On July 26th the chocolate-like discharge agsin csme on, and from this date continued almost delly to the end of the illness. I now found, on raginal examination, that the swelling in the rlght fornix was larger and more definitely rounded, distinct from the aterus, and seemed to be lower rounder, distinct from the uterus, and seemed to be lower down and consequently more easily within reach than at the
prevlous examination. Tenderness about the swelling was so prevlous examination. Tenderness about the swelling was so Investigation was not attempted.

Having made arrangements for the journey to Capetown10 mlles by rosd and four hours by traln-for operation, she travelled very comfortably on July 30 th, and arrived apparently none the worse.

$$
\text { Operation. }
$$

Next day she was seen by Mr. S. W. F. Richardson, who diagnosed a right tubal pregnancy and advised its promp removel by operation. This he did on Augast 2nd. Through a 2 -in. incislon in the middle line, midway between the pubes a 21-in. incislon in the middle line, midway between the pubes
and umbilicue, the right tabe and contents were brought out *Extract from a paper read before the Capetown Branch of the
British Medical Association. after slight delay due to some trifling adhesions, ligatured, and removed. Included with the tube was the right ovary, which contained a small cyst about the size of a large Graafian follicle and a well-marked corpus lutenm. There was no free blood or clot in the abdominal cavity. The left ovary and appendages were quite healthy.

\section{After-History.}

With the excoption of unusually severe and prolonged chloroform sickness, the patient had on uneventfal recovery and now, after a lapse of more than a year, says she never felt better in her life.

In commenting upon this case I would chlefly call attention to the unusually early date of the onset of symptoms-namely, lourteen days after the earliest possible date of conception. In Dr. Stark's case rupture occurred seventeen days after a normal menstrual period, but, according to hls patient's most emphatic assertion, nine days after the earliest possible date of conception The only reference to such early rupture that I can find in the textbooks is in Hirst's Obstetrics (1806). He says rupture may occur as early as the fourteenth day, and that in two of his own cases it happened no later than that'date.

At the annual meeting of the British Medical Association at Toronto in 1906, Professor Ross read a paper on 70 cases of ectoplc gestation upon which he had operated. In this series I can find no mention of symptoms noted as early as those in my case, and in only 5 of the 70 was operation done belore bleeding had occurred into the abdomen.

No doubt bleeding within the tube is answerable, together with the embryonic growth, for every attack of paroxysmal pain, but it is a very Interesting problem to determine why haemorrhage should occur so early at all.

Dr. Herman, in the last edition of Diseases of Women, writes :

Dr. Russell Andrews and others have shown that In tabal pregnancy the ovum develops in the wall of the tube, not in Its lumen; the trophoblasts eat their way into the wall of the tabe, as they do into the uterine mucoss in normal pregnanoy. The ovum comes to lie in a cavity bounded at one part by musenlar tissue and peritoneum.... At another by muscular tissue and mucous membrane. During the first cular tissue and mucous membrane. During the first seven or elght weeks the trophoblasts go on eating up tissue, and in the process they open up vessels so that haemorrhage takes place. This haemorrhage canses tension within the
cavity and then rupture. Thls rupture may be on the peritoneal aspect of the sac, or it may be on the mucous aspect. If the latter, the orum will escape into the lumen of the tube, and blood along with it.

That this latter mode of rupture was what occurred in my case an examination of the specimen prepared by Dr, G. W. Robertson, Government Pathologist, will show. The specimen itself gives no indication of pre-exlating tubal disease, and the patlent's history was one of marked fertility-three times pregnant within as many years.

Dr. Panl Kroemer, of Glessen, by a serles of over 4,000 sections of the Falloplan tabe, put together apon Born's system of reconstruction models, has shown that the diverticula, formerly consldered pathological conditions, are, In reality, to be lound in the normal state.

In my patient menstruation from its first appearance was always accompanied by very severe spasmodic pains coming on with the flow, lasting some hours, and causing prostration. On these occasions the chlef seat of pain was the lelt ovarian region.

In her 17th year and while at school in Belgium the monthly attacks became so serious that an operation was done, which, from the appearance and site of the scars left, was, doubtless, Alexander's operation for shortenlng the round ligaments for the cure of uterine retroposition.

From thls date, nearly elght years ago, rellel has been complete and enduring.

THE Board of Education have been informed through the Foreign Office that the Sixteenth International Congress of Americanists will be held under the presidency of Baron Weckbecker in Vienna at the University from September 9th to September 14th, 1908. The object of the Congress is to promote scientific inquiries into the history of both Americas and of their inhabitants. Communications may be oral or written, and may be in one of several languages, English included. For further information application should be made to Herr Franz Heger, Vienns (Austria), I. Burgring 7. A programme will be issued early in the summer. 